\title{
ANALISIS PENERAPAN PEMBELAJARAN BERBASIS PENDIDIKAN MATEMATIKA REALISTIK INDONESIA DI SD/MI KOTA BANDUNG
}

\author{
${ }^{1)}$ Harry Dwi Putra, ${ }^{2)}$ Puji Nurfauziah, \\ ${ }^{1)}$ harrydp.mpd@gmail.com, ${ }^{2)}$ puji_fauziahahmad@yahoo.com \\ ${ }^{1,2)}$ Program Studi Pendidikan Matematika, STKIP Siliwangi
}

\begin{abstract}
ABSTRAK
Salah satu pendekatan pembelajaran yang dapat digunakan guru berorientasi pada penerapan matematika dalam kehidupan nyata adalah Pendekatan Matematika Realistik (PMR). Di Indonesia dikenal dengan Pendidikan Matematika Realistik Indonesia (PMRI). PMR merupakan suatu teori dalam pendidikan matematika yang dikembangkan pertama kali di negeri Belanda oleh Hans Freudhental dengan nama Realistic Mathematic Education (RME). Teori ini didasarkan pada persepsi bahwa matematika adalah aktivitas manusia dan matematika harus dihubungkan secara nyata dalam konteks kehidupan siswa. Kegiatan pembelajaran lebih menekankan pada aktivitas siswa untuk mencari, menemukan, dan membangun pengetahuan, sehingga pembelajaran terpusat pada siswa. Tujuan yang ingin dicapai dari penelitian ini adalah untuk memperoleh gambaran secara mendalam mengenai proses pembelajaran matematika berbasis PMRI di SD/MI Kota Bandung dengan latar alamiah atau tanpa perlakuan. Penelitian ini merupakan penelitian kualitatif. Bentuk penelitian yang digunakan adalah participant observation dengan jenis observasi terbuka. Peneliti berperan sebagai observer langsung dan pewawancara. Dalam penelitian ini digunakan metode observasi kelas untuk mendapatkan gambaran proses pembelajaran matematika berbasis PMRI, yang kemudian akan dijadikan dasar sebagai pemilihan subjek penelitian. Penelitian ini dilaksanakan di tiga sekolah dasar, yaitu SDPN Sabang, SDPN Setiabudi, dan MIN Cicendo, sebagai sekolah mitra pembelajaran matematika berbasis PMRI. Subjek penelitian yang akan dipilih adalah siswa kelas III, karena peneliti ingin mengetahui secara khusus bagaimana penerapan PMRI terhadap materi matematika di kelas III SD/MI. Berdasarkan skor skala diferensial semantik yang dilakukan oleh dua observer rerata skor yang diperoleh oleh SDPN Sabang, SDPN Setiabudi, dan MIN Cicendo berturut-turut adalah 2,46, 2,04, dan 2,32. Ketiga rerata skor ini berada pada kriteria baik dengan interval $(3,2,1,0,-1,-2,-3)$ dan memenuhi karakteristik dalam pendekatan PMRI.
\end{abstract}

Kata Kunci: Pembelajaran Matematika, Pendidikan Matematika Realistik Indonesia.

\begin{abstract}
One of learning approachment which can be used in Mathematics appliances in the real life is a Realistic Mathematics Approachment (PMR). In Indonesia, it is known as The Indonesian Realistic Mathematics Education (PMRI). The theory is based on the assumption that mathematics is about human activities and must be connected to the student's real life. The purposes of the research are to describe about the process of Mathematics learning based PMRI in SD/MI in Bandung naturally. The research is qualitative and using the participant observation which used opened observation. The researcher is as an direct observer and interviewer. The research is used class observation methods to find some description about the process of mathematics learning based PMRI. The research is held in SDPN Sabang, SDPN Setiabudi, and MIN Cicendo as a school which has a PMRI based. The subjects of the research are the third grade, because the researcher want to know deeply about the application of PMRI in the third grade of SD/MI. according to the score of semantic differential scale by the two observer, the score mean (averages) of SDPN Sabang, SDPN Setiabudi, and MIN Cicendo are 2,46, 2,04, and 2,32. The three of the score is considered in the good criteria with the interval $(3,2,1,0,-1,-2,-3)$ and meets the characteristic in PMRI approachment.
\end{abstract}

Key Words: Mathematics Learning, Indonesian Realistic Mathematics Education. 


\section{A. PENDAHULUAN}

Salah satu aspek yang memegang peranan penting dalam kehidupan adalah pendidikan. Kualitas pendidikan yang baik dapat memajukan teknologi suatu negara. Berbagai faktor yang mempengaruhi tinggi rendahnya kualitas pendidikan. Dalam pendidikan formal (sekolah), faktor tersebut bersumber dari siswa, guru, sarana prasarana, dan lingkungan. Guru merupakan penentu keberhasilan siswa dalam belajar di sekolah. Dalam proses pembelajaran, guru mesti menggunakan berbagai strategi pembelajaran agar prestasi siswa dapat ditingkatkan. Undang-Undang Sistem Pendidikan Nasional Nomor 20 Tahun 2003 (Depdiknas, 2006:5) menyatakan bahwa pendidikan nasional berfungsi mengembangkan kemampuan dan membentuk watak serta peradaban bangsa yang bermartabat dalam rangka mencerdaskan kehidupan bangsa, bertujuan untuk berkembangnya potensi peserta didik agar menjadi manusia yang beriman dan bertakwa kepada Tuhan Yang Maha Esa, berakhlak mulia, sehat, berilmu, cakap, kreatif, mandiri, dan menjadi warga negara yang demokratis serta bertanggung jawab.

Pembelajaran di sekolah turut andil dalam mencerdaskan kehidupan bangsa. Salah satu mata pelajaran yang memberikan kontribusi positif dalam mencerdaskan kehidupan bangsa Indonesia adalah matematika. Matematika memiliki peranan yang penting dalam perkembangan ilmu pengetahuan dan teknologi. Agar dapat mengikuti perkembangan ilmu pengetahuan dan teknologi tersebut, diperlukan keterampilan intelektual yang memadai, yaitu kemampuan bernalar, berpikir sistematis, cermat, kritis dan kreatif. Keterampilan intelektual dapat dikembangkan melalui pembelajaran matematika, karena matematika memiliki struktur dan keterkaitan antar konsepnya, sehingga membuat siswa terampil berfikir rasional.

Di Indonesia, mata pelajaran matematika diberikan mulai dari tingkat Sekolah Dasar (SD), karena pentingnya pelajaran ini untuk tingkat selanjutnya. Salah satu karakteristik matematika adalah mempunyai objek yang bersifat abstrak, maksudnya objek matematika berada dalam alam pikiran manusia, sedangkan realisasinya menggunakan benda-benda yang berada di sekitar kita. Agar siswa dapat memahami konsep matematika, maka guru mesti mengaitkannya dengan kehidupan siswa sehari-hari. Menurut Permendiknas Nomor 23 Tahun 2006 (Permendiknas, 2008:134), pembelajaran matematika hendaknya dimulai dengan pengenalan masalah yang sesuai dengan situasi (contextual problem). Pernyataan tersebut semakin memperjelas bahwa matematika merupakan pelajaran yang bersifat abstrak (tidak nyata), padahal anak seusia SD masih berada pada tahap operasional konkrit. Oleh sebab itu, diperlukan suatu pendekatan yang dapat mengubah matematika yang bersifat abstrak menjadi pelajaran yang mudah dipelajari dan dapat dimengerti melalui kegiatan yang konkrit.

Salah satu pendekatan pembelajaran yang dapat digunakan guru berorientasi pada penerapan matematika dalam kehidupan nyata adalah Pendekatan Matematika Realistik (PMR). Di Indonesia dikenal dengan Pendidikan Matematika Realistik Indonesia (PMRI). PMR merupakan suatu teori dalam pendidikan matematika yang dikembangkan pertama kali di negeri Belanda oleh Hans Freudhental dengan nama Realistic Mathematic Education (RME). Teori ini didasarkan pada persepsi bahwa matematika adalah aktivitas manusia dan matematika harus dihubungkan secara nyata dalam konteks kehidupan siswa. Kegiatan pembelajaran lebih menekankan pada aktivitas siswa untuk mencari, menemukan, dan membangun pengetahuan, sehingga pembelajaran terpusat pada siswa. Menurut Suryanto (2001:3), salah satu hal yang khas dari PMRI adalah penggunaan "konteks" (masalah kontekstual). Pada pendekatan pembelajaran tradisional, yang disebut pendekatan pendidikan matematika "mekanistik", hampir seluruh isinya adalah "soal-soal yang kering" tanpa konteks realistik. Freudhental (Suryanto, 2001:2) menyatakan bahwa matematika harus dikaitkan dengan realitas, dekat dengan alam pikiran siswa dan relevan dengan masyarakat agar mempunyai nilai manusiawi.

Siswa sekolah dasar berada pada usia 7-11 tahun berada pada tahap perkembangan kognitif operasional konkrit (Sudharto, 2009). Penanaman konsep dasar matematika menggunakan permasalahan kontekstual yang sering terjadi dalam kehidupan sehari-hari, akan membuat siswa merasa dekat dengan matematika, karena permasalahan matematika juga terjadi dalam kehidupan sehari-hari di sekitar lingkungan mereka. Hasil penelitian Muchlis (2012:136) pada siswa kelas 2 di SD Kartika 1.10 Padang menunjukkan bahwa kemampuan pemecahan masalah matematika siswa yang belajar dengan pendekatan PMRI lebih baik secara signifikan dari 
pada siswa yang belajar dengan pendekatan konvensional, selain itu terjadi perkembangan kemampuan pemecahan masalah yang ditunjukkan dengan kemampuan siswa dalam menyelesaikan soal-soal yang tidak rutin, dan usaha yang dilakukan guru untuk meningkatkan kemampuan pemecahan masalah dengan membuat perangkat pembelajaran berbasis PMRI dan melatih siswa untuk menyelesaikan masalah tidak rutin.

Selanjutnya, hasil penelitian Saefudin (2012:37) menyimpulkan bahwa pengembangan kemampuan berpikir kreatif dalam pembelajaran matematika dengan pendekatan PMRI dikarenakan adanya prinsip dan karakteristik PMRI yang diterapkan dalam pembelajaran. Prinsip penemuan kembali suatu konsep matematika memungkinkan siswa untuk mengalami sendiri penemuan konsep tersebut. Karakteristik pemodelan dalam pemecahan masalah matematika juga memungkinkan untuk mengembangkan kemampuan berpikir kreatif siswa.

Melalui prinsip tersebut, memungkinkan siswa melakukan aktivitas-aktivitas kreatif dalam pemecahan masalah matematika, terutama masalah matematika terbuka. Mengingat pentingnya penerapan PMRI di tingkat sekolah dasar, maka peneliti ingin melakukan observasi dan analisis mendalam tentang bagaimana guru sekolah dasar di kota Bandung menerapkan PMRI dalam pembelajaran matematika. Rumusan masalah dalam penelitian ini adalah "Bagaimana penerapan pembelajaran matematika berbasis PMRI di SD/MI Kota Bandung?" Penelitian ini bertujuan untuk menganalisis penerapan pembelajaran matematika berbasis PMRI di SD/MI Kota Bandung. Hasil penelitian ini diharapkan bermanfaat dalam memberikan informasi kepada pendidik dan calon pendidik agar selalu meningkatkan kualitas pendidikan, salah satunya dengan menerapkan pendekatan PMRI dalam pembelajaran.

\section{B. KAJIAN TEORI DAN METODE}

\section{Kajian Teori}

\section{a. Pembelajaran Matematika}

Menurut Bruner (Hudoyo, 2000:56), pembelajaran matematika adalah belajar tentang konsep dan struktur matematika yang terdapat dalam materi yang dipelajari serta mencari hubungan antara konsep dan struktur matematika di dalamnya. Pada hakekatnya belajar matematika sangat terkait dengan pola berpikir sistematis, yaitu berpikir merumuskan sesuatu yang dilakukan atau yang berhubungan dengan struktur-struktur yang telah dibentuk dari hal yang ada.

Dalam proses pembelajaran matematika, para siswa dibiasakan untuk memperoleh pemahaman melalui pengalaman tentang sifat-sifat yang dimiliki dan yang tidak dimiliki dari sekumpulan objek (abstraksi). Melalui pengamatan terhadap contoh dan bukan contoh diharapkan siswa mampu menangkap pengertian suatu konsep. Selanjutnya, dengan abstraksi ini, siswa dilatih untuk membuat perkiraan, terkaan, atau kecenderungan berdasarkan kepada pengalaman atau pengetahuan yang dikembangkan melalui contoh-contoh khusus (generalisasi). Di dalam proses penalarannya dikembangkan pola pikir induktif maupun deduktif. Namun, semuanya itu harus disesuaikan dengan perkembangan kemampuan siswa, sehingga pada akhirnya akan sangat membantu kelancaran proses pembelajaran matematika di sekolah.

Suherman (2003:56-57) menyebutkan tiga fungsi pembelajaran matematika, yaitu:

1) Alat untuk memahami dan menyampaikan informasi, misalnya menggunakan tabel-tabel atau model-model matematika untuk menyederhanakan soal-soal cerita atau soalsoal uraian matematika.

2) Upaya pembentukan pola pikir dalam pemahaman suatu pengertian maupun dalam penalaran suatu hubungan di antara pengertianpengertian itu.

3) Ilmu pengetahuan, di mana matematika senantiasa mencari kebenaran dan mencoba mengembangkan penemuan-penemuan dengan mengikuti tata cara yang tepat.

\section{b. Pendidikan Matematika Realistik Indonesia (PMRI)}

PMRI merupakan pendekatan yang sama pengertiannya dengan pendekatan RME (Realistic Mathematics Educations). RME merupakan suatu pendekatan yang dicetuskan oleh Institut Freudhental. Institut ini didirikan pada tahun 1971, berada di bawah Utrecht University, Belanda. Institut Freudhental berkeyakinan bahwa siswa tidak boleh dipandang sebagai passive receivers of ready-made mathematic (penerima pasif matematika yang sudah jadi), tetapi pendidikan harus mengarahkan siswa kepada penggunaan berbagai situasi dan kesempatan untuk menemukan 
kembali matematika dengan cara mereka sendiri (Novikasari, 2007:6). melalui kenyataan dan hal konkrit yang bisa dikenal siswa pada saat pembelajaran matematika, siswa diharapkan bisa menemukan konsep matematika.

Dickinson (2010:78) menyebutkan bahwa "experience shows that, through staying connected with the context, students are able to continue to make sense of what they are doing, and do not need to resort to memorising rules and procedures which have no meaning for them. 'Mathematic' and 'context' are not separated". Pendapat tersebut menerangkan bahwa melalui kenyataan yang dihubungkan dengan konsep, siswa mampu memahami apa yang guru ajarkan, dan tidak diperlukan lagi metode untuk menghafal konsep matematika. Matematika dan kenyataan tidak dapat dipisahkan, karena kehidupan siswa tidak terlepas dari hal nyata yang dapat dilihat, dipegang, dan dilakukan siswa setiap harinya.

PMRI mempunyai pengertian yang sama dengan PMR dan RME, yaitu suatu pendekatan dalam pembelajaran matematika yang didasari atas pandangan bahwa matematika sebagai aktivitas manusia. Matematika diusahakan dekat dengan kehidupan siswa, dan dikaitkan dengan kehidupan sehari-hari yang bersifat konkrit. Menurut Streefland (Kesumawati, 2008:135) bahwa dalam proses pembelajarannya siswa diberi kesempatan yang luas untuk belajar melakukan aktivitas matematika dengan berinteraksi serta bernegosiasi baik dengan sesama siswa maupun dengan guru. Siswa tidak dipandang sebagai penerima pasif matematika yang sudah jadi, pendidikan matematika harus diarahkan pada penggunaan berbagai situasi dan kesempatan yang memungkinkan siswa menemukan kembali matematika berdasarkan usaha mereka sendiri.

Dickinson (2010:78) menyebutkan bahwa:

"in RME, contexts are used not only to illustrate the applicability and relevance of Mathematic in the real world, but also as a source for the learning of Mathematic itself. Contexts can be taken from the real world, from fiction or from an area of Mathematic that students are already familiar with".

Pendapat tersebut menjelaskan bahwa dalam pendidikan matematika realistik, hal nyata yang digunakan guru dalam pengajaran tidak hanya digunakan untuk menggambarkan penerapan dan kesesuaian konsep matematika di dunia nyata, tetapi juga sebagai sumber untuk pembelajaran matematika. Hal nyata dalam pengajaran dapat berasal dari dunia nyata dan dari cerita fiksi yang sudah dikenal dan akrab dengan kehidupan siswa.

Konsep PMRI sama dengan konsep RME. Menurut Freudhental (Tandililing, 2012:2), konsep-konsep RME yang berkaitan dengan pembelajaran matematik, yaitu:

1) Matematisasi, artinya bahwa ilmu tidak lagi hanya sekedar kumpulan pengalaman, ilmu melibatkan kegiatan mengorganisasi pengalaman dengan menggunakan matematika yang disebut dengan mathematizing. Ada dua macam matematisasi, yaitu matematisasi horizontal dan matematisasi vertikal. Matematisasi horizontal adalah matematisasi pengalaman matematis dari realitas, sedangkan matematisasi vertikal disebut matematisasi matematika.

2) Matematika sebagai produk jadi dan matematika sebagai kegiatan pembelajaran yang berdasarkan paham bahwa matematika harus diajarkan sebagai barang jadi atau sebagai sistem deduktif, menghasilkan pandangan bahwa matematika tidak berguna karena pembelajaran matematika hanya berisi kegiatan menghafalkan aksioma, definisi, teorema, serta penerapannya pada soal-soal.

3) Kegiatan atau aktivitas, pengetahuan, dan kecakapan yang diperoleh dengan cara penemuan akan lebih dipahami dan lebih awet dalam ingatan daripada pengetahuan atau kecakapan yang diperoleh dengan cara pasif.

4) Reinvention atau penemuan, artinya bahwa kegiatan pembelajaran matematika harus berdasarkan pada penafsiran dan analisis matematika.

Pelaksanaan pembelajaran dengan menggunakan PMRI harus dapat dilaksanakan dengan baik agar tujuan pembelajaran dapat tercapai. Sebelum menerapkan pembelajaran harus mengetahui prinsip utama dari RME. Menurut Gravemeijer (1994), ada tiga prinsip kunci RME, yaitu:

a) Guided Reinvention. Memberikan kesempatan bagi siswa untuk melakukan matematisasi dengan masalah kontekstual yang realistik. Siswa didorong untuk aktif bekerja mengkonstruksi pengetahuan sendiri.

b) Didactical Phenomenology. Pembelajaran matematika yang cenderung memberikan informasi matematika siap jadi digantikan dengan pembelajaran yang diawali dengan permasalahan yang dapat dipecahkan siswa 
dengan caranya sendiri, dengan begitu pembelajaran berorientasi pada siswa.

c) Self-Developed Models. Model dibangun sendiri oleh siswa. Pada waktu siswa memecahkan permasalahan secara individu maupun kelompok, diharapkan siswa mampu mengembangkan suatu model dalam matematika horizontal ataupun vertikal.

PMRI memiliki karakteristik-karakteristik yang harus dikenal dan dipahami oleh seorang guru yang akan menggunakan PMRI. Treffers (1991) merumuskan lima karakteristik PMRI, yaitu:

1) Penggunaan konteks. Konteks atau permasalahan realistik digunakan sebagai titik awal pembelajaran matematika. Konteks tidak harus berupa masalah dunia nyata namun bisa dalam bentuk permainan, penggunaan alat peraga, atau situasi lain selama hal tersebut bermakna dan bisa dibayangkan dalam pikiran siswa.

2) Penggunaan model untuk matematisasi progresif. Penggunaan model berfungsi sebagai jembatan dari pengetahuan matematika tingkat konkrit menuju pengetahuan matematika tingkat formal.

3) Pemanfaatan hasil konstruksi siswa. Hasil konstruksi siswa digunakan untuk landasan pengembangan konsep matematika sekaligus juga mengembangkan aktivitas dan kreativitas siswa.

4) Interaktivitas. Proses belajar siswa akan menjadi lebih singkat dan bermakna ketika siswa saling mengkomunikasikan hasil kerja dan gagasan mereka. Pemanfaatan interaksi dalam pembelajaran matematika bermanfaat dalam mengembangkan kemampuan kognitif dan afektif siswa secara simultan.

5) Keterkaitan. Konsep-konsep dalam matematika tidak bersifat parsial, namun banyak konsep matematika yang memiliki keterkaitan. Melalui keterkaitan ini, satu pembelajaran matematika diharapkan bisa mengenalkan dan membangun lebih dari satu konsep matematika secara bersamaan.

PMRI sebagai salah satu pendekatan yang dapat digunakan dalam pembelajaran matematika mempunyai keunggulan dan kelemahan yang dapat menjadi pertimbangan dalam menggunakan suatu pendekatan. Asmin (Tandililing, 2012:3) menguraikan keunggulan dan kelemahan PMRI, yaitu:

a) Keunggulan PMRI, di antaranya: siswa tidak mudah lupa dengan pengetahuannya, suasana dalam proses pembelajaran menyenangkan, siswa merasa dihargai dan semakin terbuka, memupuk kerjasama dalam kelompok, melatih keberanian siswa karena harus menjelaskan jawabannya, melatih siswa untuk terbiasa berpikir dan mengemukakan pendapat, dan pendidikan budi pekerti.

b) Kelemahan PMRI, di antaranya: siswa masih kesulitan dalam menemukan sendiri jawabannya karena sudah terbiasa diberi informasi terlebih dahulu, membutuhkan waktu yang lama bagi siswa yang lemah, siswa yang pandai kadang-kadang tidak sabar untuk menanti temannya yang belum selesai; dan membutuhkan alat peraga yang sesuai dengan situasi pembelajaran saat itu.

Upaya untuk mengatasi kelemahan PMRI agar tidak berdampak negatif terhadap siswa, di antaranya: membimbing dan mengarahkan siswa yang kesulitan menemukan jawaban dari permasalahan yang guru ajukan, memberikan tambahan waktu berpikir bagi siswa yang mempunyai kelemahan pemahaman, mengarahkan siswa yang pandai untuk dapat bersabar menunggu siswa yang belum menemukan jawaban, serta menggunakan alat peraga sesuai dengan kondisi kelas dan jumlah siswa.

PMRI mempunyai langkah pembelajaran yang sama dengan RME. Zulkardi (Hartono, 2007:20) secara umum menguraikan langkah-langkah pembelajaran PMRI, sebagai berikut:

1) Persiapan. Selain menyiapkan masalah kontekstual, guru harus benar-benar memahami masalah dan memiliki berbagai macam strategi yang mungkin akan ditempuh siswa dalam menyelesaikannya.

2) Pembukaan. Pada bagian ini siswa diperkenalkan dengan strategi pembelajaran yang dipakai dan diperkenalkan kepada masalah dari dunia nyata, kemudian siswa diminta untuk memecahkan masalah tersebut dengan cara mereka sendiri.

3) Proses pembelajaran. Siswa mencoba berbagai strategi untuk menyelesaikan masalah sesuai dengan pengalamannya, dapat dilakukan secara perorangan maupun secara kelompok, kemudian setiap siswa atau kelompok mempresentasikan hasil kerjanya di depan siswa atau kelompok lain. Siswa atau kelompok lain memberikan tanggapan terhadap hasil kerja siswa atau kelompok penyaji. Guru mengamati jalannya diskusi kelas dan memberi tanggapan sambil 
mengarahkan siswa untuk mendapatkan strategi terbaik serta menemukan aturan atau prinsip yang bersifat lebih umum.

4) Penutup. Setelah mencapai kesepakatan tentang strategi terbaik melalui diskusi kelas, siswa diajak menarik kesimpulan dari pelajaran saat itu. Pada akhir pembelajaran siswa harus mengerjakan soal evaluasi dalam bentuk matematika formal.

Konsepsi pendekatan PMRI tentang pembelajaran matematika (Supinah, 2009:77), sebagai berikut:

a) Memulai pelajaran dengan mengajukan masalah yang nyata bagi siswa sesuai dengan pengalaman dan tingkat pengetahuannya, sehingga siswa segera terlibat dalam pelajaran secara bermakna.

b) Permasalahan yang diberikan tentu harus diarahkan sesuai dengan tujuan yang ingin dicapai dalam pelajaran tersebut.

c) Siswa mengembangkan atau menciptakan model-model simbolik secara informal terhadap persoalan atau masalah yang diajukan.

d) Pengajaran berlangsung secara interaktif siswa menjelaskan dan memberikan alasan terhadap jawaban yang diberikannya, memahami jawaban temannya, setuju terhadap jawaban temannya, menyatakan ketidaksetujuan, mencari alternatif penyelesaian yang lain, dan melakukan refleksi terhadap setiap langkah yang ditempuh atau terhadap hasil pelajaran.

\section{Metode}

Tujuan yang ingin dicapai dari penelitian ini adalah untuk memperoleh gambaran secara mendalam mengenai proses pembelajaran matematika berbasis PMRI di SD Kota Bandung dengan latar alamiah atau tanpa perlakuan, oleh karena itu penelitian ini merupakan penelitian kualitatif (Creswell, 2008). Data yang dikumpulkan berbentuk kata-kata dan gambar. Fokus perhatian pada proses dan hasil, tidak terdapat pengujian hipotesis melainkan analisis induktif dengan desain yang fleksibel untuk melihat hubungan-hubungan yang terdapat antara temuan di lapangan dengan teori yang ada. Bentuk penelitian yang digunakan adalah participant observation dengan jenis observasi terbuka (Fraenkel, 2012). Peneliti berperan sebagai observer langsung dan pewawancara. Peneliti menjadi instrumen dalam penelitian ini. Terkait dengan hal tersebut, maka dalam penelitian ini akan digunakan metode observasi kelas untuk mendapatkan gambaran proses pembelajaran matematika berbasis PMRI, yang kemudian akan dijadikan dasar sebagai pemilihan subjek penelitian. Selanjutnya, digunakan metode wawancara yang dapat dimanfaatkan untuk melakukan triangulasi pada proses analisis data.

Penelitian dilaksanakan di tiga sekolah dasar, yaitu MIN Cicendo, SDPN Sabang, SD Lab School UPI Setiabudi sebagai sekolah mitra pembelajaran matematika berbasis PMRI di kota Bandung. Subjek penelitian yang akan dipilih adalah siswa kelas III, karena peneliti ingin mengetahui secara khusus bagaimana penerapan PMRI terhadap materi matematika di kelas III SD pada ketiga sekolah tersebut. Pengumpulan data dilakukan dengan metode observasi dan wawancara. Instrumen dalam penelitian ini adalah peneliti sendiri yang dibantu dengan instrumen pedoman observasi dan pedoman wawancara, sedangkan teknik pengumpulan data dilakukan dengan:

a. Observasi kelas selama proses pembelajaran berlangsung dengan memanfaatkan rekaman audiovisual dari beberapa titik di kelas. Perekaman difokuskan pada cara guru menerapkan pendekatan PMRI selama pembelajaran, aktivitas komunikasi yang berlangsung sesama siswa dan antara siswa dengan guru, agar dapat dikaji juga respon siswa terhadap tindakan guru. Peneliti juga menggunakan lembar pedoman observasi berupa skala diferensial semantik terdiri dari 14 butir pernyataan dengan rentang skor $(3,2$, $1,0,-1,-2,-3)$. Cara Penskoran dari skala diferensial semantik tersebut, sebagai berikut:

$$
\begin{array}{lll}
3 \leq A<2,67 & : & A \text { (Amat Baik) } \\
2,67 \leq B<1,68 & : & B \text { (Baik) } \\
1,68 \leq C<-1,68 & : & C \text { (Cukup Baik) } \\
-1,68 \leq D<-2,67 & : & D \text { (Kurang Baik) } \\
-2,67 \leq E<-3 & : & E \text { (Tidak Baik) }
\end{array}
$$

Selain itu, juga digunakan catatan lapangan untuk mengobservasi kecenderungan aktivitas siswa, sehingga dapat dikenali siswa-siswa yang aktif dalam proses pembelajaran sebagai acuan untuk menentukan subjek wawancara.

b. Wawancara dilaksanakan setelah proses pembelajaran berlangsung, siswa diajukan beberapa pertanyaan yang potensial terkait topik yang telah diajarkan untuk mendapatkan gambaran yang lebih detail tentang keberhasilan penerapan pendekatan PMRI dalam pembelajaran. Sebelum wawancara 
berlangsung, disusun suatu pedoman wawancara yang rinci.

Data dalam penelitian ini berbentuk kata-kata, tindakan, dan dokumen. Data yang diperoleh dari hasil observasi tentang penerapan pendekatan PMRI dalam proses pembelajaran di kelas dinarasikan. Data hasil wawancara dibuat transkripnya, setelah itu dibandingkan dengan data-data yang lain untuk analisis lebih lanjut. Analisis data yang digunakan adalah analytic induction dan constant comparison. Data akan dikelompokkan ke dalam kategori, lalu dilakukan perbandingan silang antar kategori tersebut (Alwasilah, 2003).

\section{HASIL DAN PEMBAHASAN}

Penerapan pendekatan PMRI dalam pembelajaran matematika dilakukan oleh SDPN Sabang, SDPN Setiabudi, dan MIN Cicendo. Pada penelitian ini, difokuskan untuk menganalisis penerapan pendekatan PMRI khusus di kelas III. Berikut disajikan hasil observasi di masing-masing sekolah oleh dua observer menggunakan skala diferensial semantik.

\section{Hasil Observasi Penerapan PMRI di Kelas III SDPN Sabang}

Berikut ini disajikan hasil observasi oleh dua observer (NJ dan PN) dalam pembelajaran matematika dengan pendekatan PMRI pada tema Kegiatanku dengan materi Operasi Hitung Bilangan Sampai Tiga Angka pada Tabel 1.

\section{Tabel 1. Hasil Observasi Penerapan PMRI di Kelas III SDPN Sabang}

\begin{tabular}{|c|c|c|c|}
\hline \multirow[t]{2}{*}{ No. } & \multirow[t]{2}{*}{ Pernyataan } & \multicolumn{2}{|c|}{$\begin{array}{l}\text { Skor dari } \\
\text { Observer }\end{array}$} \\
\hline & & NJ & PN \\
\hline 1. & $\begin{array}{l}\text { Pembelajaran dimulai dengan } \\
\text { masalah kontekstual. }\end{array}$ & 3 & 3 \\
\hline 2. & Pembelajarannya Realistik. & 3 & 3 \\
\hline 3. & Pembelajarannya Tematik. & 2 & 1 \\
\hline 4. & $\begin{array}{l}\text { Menggunakan metode } \\
\text { penemuan. }\end{array}$ & 2 & 2 \\
\hline 5. & $\begin{array}{l}\text { Menggunakan pendekatan } \\
\text { konstruktivisme. }\end{array}$ & 2 & 3 \\
\hline 6. & $\begin{array}{l}\text { Pembelajarannya dimulai dari } \\
\text { aktivitas tidak formal ke } \\
\text { bentuk formal (bawah ke } \\
\text { atas). }\end{array}$ & 3 & 2 \\
\hline 7. & $\begin{array}{l}\text { Siswa aktif dalam } \\
\text { pembelajaran }\end{array}$ & 2 & 3 \\
\hline
\end{tabular}

\begin{tabular}{|c|c|c|c|}
\hline 8. & $\begin{array}{l}\text { Guru membuat RPP sebelum } \\
\text { memulai pembelajaran. }\end{array}$ & 3 & 3 \\
\hline 9. & $\begin{array}{l}\text { Materi PMRI dirancang dari } \\
\text { buku PMRI. }\end{array}$ & 0 & 1 \\
\hline 10. & $\begin{array}{l}\text { Guru membuat LKS sebelum } \\
\text { pembelajaran. }\end{array}$ & 3 & 3 \\
\hline 11. & $\begin{array}{l}\text { Siswa mengerjakan LKS } \\
\text { dalam pembelajaran. }\end{array}$ & 3 & 3 \\
\hline 12. & $\begin{array}{l}\text { Guru membahas hasil } \\
\text { pekerjaan siswa pada LKS. }\end{array}$ & 3 & 3 \\
\hline 13. & $\begin{array}{l}\text { Siswa menjawab, bertanya, } \\
\text { dsb. setelah diizinkan guru. }\end{array}$ & 3 & 3 \\
\hline 14. & $\begin{array}{l}\text { Guru melakukan refleksi di } \\
\text { akhir pembelajaran. }\end{array}$ & 3 & 1 \\
\hline & $\begin{array}{l}\text { Jumlah } \\
\text { Rerata }\end{array}$ & $\begin{array}{c}35 \\
2,50\end{array}$ & $\begin{array}{c}34 \\
2,43\end{array}$ \\
\hline
\end{tabular}

Berdasarkan Tabel 1 terlihat bahwa rerata skor hasil observasi yang diperoleh dari kedua observer tidak terlalu berbeda, hanya selisih 0,07 . Rerata skor dari kedua observer adalah 2,46, ini menunjukkan bahwa dari skala diferensial semantik berada pada daerah yang positif, artinya penerapan pendekatan PMRI di SDPN Sabang sudah baik. Pembelajaran matematika di kelas III SDPN Sabang menggunakan Tematik. Ketika peneliti mengamati pembelajaran matematika dengan pendekatan PMRI pada jam pertama, terlihat bahwa sebelum pembelajaran dimulai, siswa berbaris terlebih dahulu sebelum memasuki kelas dan mengisi absen dinding sesuai dengan nomor urutnya.

Pada awal pembelajaran guru memberikan salam dan berdoa, memeriksa kehadiran dan kesiapan siswa dalam mengikuti pelajaran, dan mempersiapkan materi yang akan diajarkan, yaitu melakukan operasi hitung bilangan sampai tiga angka. Siswa diminta membentuk kelompok dengan memilih anggotanya sendiri dengan menghitung semua siswa dalam kelas dan membaginya menjadi beberapa anggota kelompok. Pada tahap kegiatan inti, siswa satu persatu mengambil dua buah kartu bilangan yang disediakan guru, setiap siswa menulis kartu bilangan yang diperoleh kemudian melakukan operasi hitung, guru membimbing siswa dalam mengerjakannya. Kegiatan ini merupakan bentuk dari kontekstual dan realistik dengan adanya kartu bilangan yang dapat dimanipulasi. Setelah siswa selesai membaca ulang teks cerita, guru memberikan penjelasan dan tanya jawab dengan siswa tentang operasi hitung yang ada dalam teks bacaan. Salah satu siswa maju ke depan untuk menghitung, berapa jumlah kaki singa yang ada di dalam kandang pada teks bacaan "Tamasya ke 
Kebun Binatang". Guru memberikan Lembar Kerja Siswa (LKS) berisi soal latihan.

Pada akhir pembelajaran, guru mengumpulkan LKS dan memberikan motivasi tentang materi yang sudah dipelajari. Seharusnya, guru merefleksi dulu materi yang telah dipahami siswa, karena bisa saja terdapat kesalahpahaman di antara siswa tentang konsep yang telah mereka pelajari. Selanjutnya, guru menutup pembelajaran dengan mengucapkan salam. Aktivitas pembelajaran ini sesuai dengan Rencana Pelaksanaan Pembelajaran (RPP) yang telah dibuat guru sebelum mengajar.

\section{Hasil Observasi Penerapan PMRI di Kelas III SDPN Setiabudi}

Berikut ini disajikan hasil observasi oleh dua observer (MS dan PN) dalam pembelajaran matematika dengan pendekatan PMRI di SDPN Setiabudi pada Tabel 2 .

\section{Tabel 2. Hasil Observasi Penerapan PMRI di Kelas III SDPN Setiabudi}

\begin{tabular}{|c|c|c|c|}
\hline \multirow[t]{2}{*}{ No. } & \multirow[t]{2}{*}{ Pernyataan } & \multicolumn{2}{|c|}{$\begin{array}{l}\text { Skor dari } \\
\text { Observer }\end{array}$} \\
\hline & & MS & PN \\
\hline 1. & $\begin{array}{l}\text { Pembelajaran dimulai } \\
\text { dengan masalah kontekstual. }\end{array}$ & 3 & 3 \\
\hline 2. & Pembelajarannya Realistik. & 3 & 3 \\
\hline 3. & Pembelajarannya Tematik. & 0 & 1 \\
\hline 4. & $\begin{array}{l}\text { Menggunakan metode } \\
\text { penemuan. }\end{array}$ & 3 & 2 \\
\hline 5. & $\begin{array}{l}\text { Menggunakan pendekatan } \\
\text { konstruktivisme. }\end{array}$ & 3 & 2 \\
\hline 6. & $\begin{array}{l}\text { Pembelajarannya dimulai } \\
\text { dari aktivitas tidak formal ke } \\
\text { bentuk formal (bawah ke } \\
\text { atas). }\end{array}$ & 3 & 3 \\
\hline 7. & $\begin{array}{l}\text { Siswa aktif dalam } \\
\text { pembelajaran }\end{array}$ & 3 & 3 \\
\hline 8. & $\begin{array}{l}\text { Guru membuat RPP sebelum } \\
\text { memulai pembelajaran. }\end{array}$ & 2 & -3 \\
\hline 9. & $\begin{array}{l}\text { Materi PMRI dirancang dari } \\
\text { buku PMRI. }\end{array}$ & 2 & 1 \\
\hline 10. & $\begin{array}{l}\text { Guru membuat LKS sebelum } \\
\text { pembelajaran. }\end{array}$ & 3 & 0 \\
\hline 11. & $\begin{array}{l}\text { Siswa mengerjakan LKS } \\
\text { dalam pembelajaran. }\end{array}$ & 3 & 0 \\
\hline 12. & $\begin{array}{l}\text { Guru membahas hasil } \\
\text { pekerjaan siswa pada LKS. }\end{array}$ & 3 & 0 \\
\hline 13. & $\begin{array}{l}\text { Siswa menjawab, bertanya, } \\
\text { dsb. setelah diizinkan guru. }\end{array}$ & 3 & 3 \\
\hline 14. & $\begin{array}{l}\text { Guru melakukan refleksi di } \\
\text { akhir pembelajaran. }\end{array}$ & 3 & 2 \\
\hline & Jumlah & 37 & 20 \\
\hline & Rerata & 2.64 & 1,43 \\
\hline
\end{tabular}

Berdasarkan Tabel 2 terlihat bahwa rerata skor hasil observasi yang diperoleh kedua observer terdapat perbedaan dengan selisih 1,21. Penskoran yang sangat berbeda terletak pada pernyataan tentang pembuatan RPP dan LKS untuk pembelajaran. Ini disebabkan karena observer tidak melakukan observasi pada waktu yang bersamaan, sehingga guru model yang diamati tidak menggunakan RPP dan LKS ketika diobservasi oleh PN. Rerata yang diperoleh dari kedua observer adalah 2,04, ini menunjukkan bahwa penerapan pendekatan PMRI di SDPN Setiabudi sudah baik. Pembelajaran matematika di kelas III SDPN Setiabudi tidak menggunakan Tematik. Ketika peneliti mulai mengamati pembelajaran matematika dengan pendekatan PMRI, siswa sudah berada di dalam kelas karena pelajaran matematika saat itu tidak di jam pertama. Pada awal pembelajaran guru memberikan salam dan berdoa, memeriksa kehadiran dan kesiapan siswa dalam mengikuti pelajaran, dan mempersiapkan materi yang akan diajarkan, yaitu menentukan hubungan antar satuan waktu.

Pada tahap kegiatan inti, siswa mengambil satu kalender yang disediakan guru, dan mendiskusikan tentang hubungan antar satuan waktu pada kalender tersebut dengan teman sebangkunya.

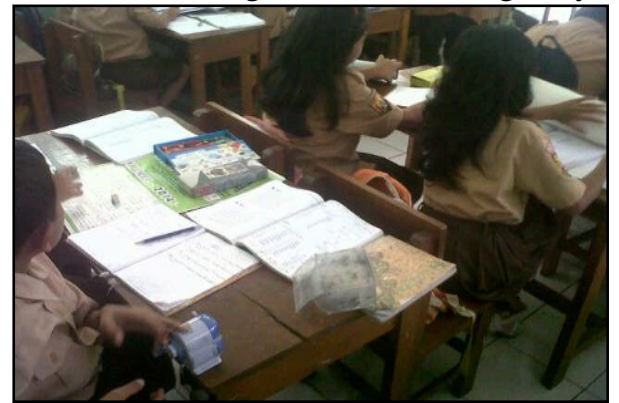

\section{Gambar 1. Siswa Berdiskusi dengan Teman Sebangku}

Guru membimbing siswa dalam mencari hubungan antar waktu dari kalender. Ini merupakan kegiatan penemuan yang sedang dilakukan siswa. Setelah siswa selesai memahami hubungan antar waktu, guru memberikan penjelasan dan tanya jawab dengan siswa. Salah satu siswa maju ke depan untuk menyampaikan hubungan antar waktu melalui kalender tersebut. 


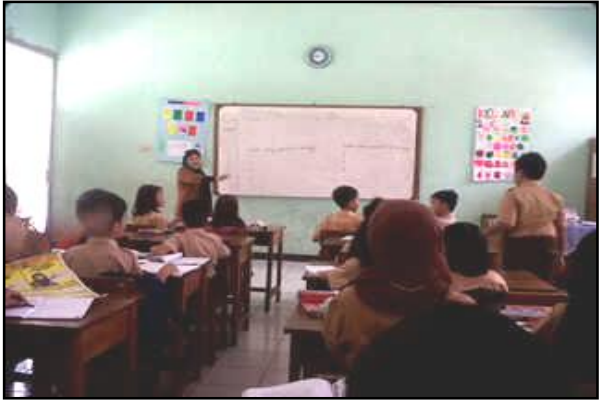

Gambar 2. Siswa di Depan Kelas Menyampaikan Hasil Pekerjaannya

Guru memberikan LKS berisi soal latihan. LKS yang dibuat guru adalah bukan berasal dari buku PMRI tetapi hasil kreativitas guru itu sendiri. Namun, konsep yang dikuasai siswa belum sampai pada bentuk formal, karena siswa hanya memanipulasi alat peraga dalam menyelesaikan soal pada LKS. Pada akhir pembelajaran, guru mengumpulkan LKS dan memberikan motivasi tentang materi yang sudah dipelajari. Guru menutup pembelajaran dengan mengucapkan salam. Dalam hal ini guru tidak melakukan refleksi terhadap materi pembelajaran, hal ini dapat menyebabkan terjadi kesalahpahaman konsep di antara siswa.

\section{Hasil Observasi Penerapan PMRI di Kelas III MIN Cicendo}

Berikut ini disajikan hasil observasi oleh dua observer (OA dan PN) dalam pembelajaran matematika dengan pendekatan PMRI pada dengan materi Melakukan Operasi Hitung Bilangan Sampai Tiga Angka pada Tabel 3.

\section{Tabel 3. Hasil Observasi Penerapan PMRI di} Kelas III MIN Cicendo

\begin{tabular}{|c|c|c|c|}
\hline \multirow[t]{2}{*}{ No. } & \multirow[t]{2}{*}{ Pernyataan } & \multicolumn{2}{|c|}{$\begin{array}{l}\text { Skor dari } \\
\text { Observer }\end{array}$} \\
\hline & & $\mathbf{O A}$ & $\mathbf{P N}$ \\
\hline 1. & $\begin{array}{l}\text { Pembelajaran dimulai } \\
\text { dengan masalah kontekstual. }\end{array}$ & 3 & 3 \\
\hline 2. & Pembelajarannya Realistik. & 3 & 3 \\
\hline 3. & Pembelajarannya Tematik. & 1 & 1 \\
\hline 4. & $\begin{array}{l}\text { Menggunakan metode } \\
\text { penemuan. }\end{array}$ & 3 & 3 \\
\hline 5. & $\begin{array}{l}\text { Menggunakan pendekatan } \\
\text { konstruktivisme. }\end{array}$ & 3 & 3 \\
\hline 6. & $\begin{array}{l}\text { Pembelajarannya dimulai } \\
\text { dari aktivitas tidak formal ke } \\
\text { bentuk formal (bawah ke } \\
\text { atas). }\end{array}$ & 3 & 3 \\
\hline 7. & $\begin{array}{l}\text { Siswa aktif dalam } \\
\text { pembelajaran }\end{array}$ & 3 & 3 \\
\hline 8. & $\begin{array}{l}\text { Guru membuat RPP sebelum } \\
\text { memulai pembelajaran. }\end{array}$ & 3 & 1 \\
\hline
\end{tabular}

\begin{tabular}{|c|c|c|c|}
\hline 9. & $\begin{array}{l}\text { Materi PMRI dirancang dari } \\
\text { buku PMRI. }\end{array}$ & -3 & 1 \\
\hline 10. & $\begin{array}{l}\text { Guru membuat LKS sebelum } \\
\text { pembelajaran. }\end{array}$ & 3 & 2 \\
\hline 11. & $\begin{array}{l}\text { Siswa mengerjakan LKS } \\
\text { dalam pembelajaran. }\end{array}$ & 3 & 2 \\
\hline 12. & $\begin{array}{l}\text { Guru membahas hasil } \\
\text { pekerjaan siswa pada LKS. }\end{array}$ & 3 & 2 \\
\hline 13. & $\begin{array}{l}\text { Siswa menjawab, bertanya, } \\
\text { dsb. setelah diizinkan guru. }\end{array}$ & 2 & 3 \\
\hline 14. & $\begin{array}{l}\text { Guru melakukan refleksi di } \\
\text { akhir pembelajaran. }\end{array}$ & 3 & 2 \\
\hline & $\begin{array}{l}\text { Jumlah } \\
\text { Rerata }\end{array}$ & $\begin{array}{c}33 \\
236\end{array}$ & $\begin{array}{c}32 \\
229\end{array}$ \\
\hline
\end{tabular}

Berdasarkan Tabel 3 terlihat bahwa rerata skor hasil observasi yang diperoleh kedua observer tidak terlalu berbeda, hanya selisih 0,07 . Rerata yang diperoleh dari kedua observer adalah 2,32, ini menunjukkan bahwa penerapan pendekatan PMRI di MIN Cicendo sudah baik. Pembelajaran matematika di kelas III MIN Cicendo tidak menggunakan Tematik. Ketika peneliti mengamati pembelajaran matematika dengan pendekatan PMRI, terlihat bahwa sebelum pembelajaran dimulai, siswa berbaris terlebih dahulu sebelum memasuki kelas dan mengisi absen dinding sesuai dengan nomor urut.

Pada awal pembelajaran guru mengkondisikan siswa agar siap memulai pelajaran, memeriksa kehadiran, dan mempersiapkan materi yang akan diajarkan, yaitu memecahkan masalah perhitungan termasuk yang berkaitan dengan uang. Sebelum memulai materi, guru mengajukan pertanyaan kepada siswa, "Siapa hari ini yang membawa uang?" Uang ini merupakan media yang akan digunakan untuk menyampaikan kepada siswa tentang konsep operasi hitung bilangan.

Setelah terjadi kegiatan tanya jawab antara guru dan siswa tentang nilai uang yang dibawa siswa, guru memperlihatkan berbagai mata uang dalam bentuk tiruan yang beredar di negara kita. Siswa diminta membentuk empat kelompok dengan menghitung semua siswa dalam kelas dan membaginya menjadi empat kelompok, sehingga siswa memperoleh banyaknya anggota dari tiaptiap kelompok. 


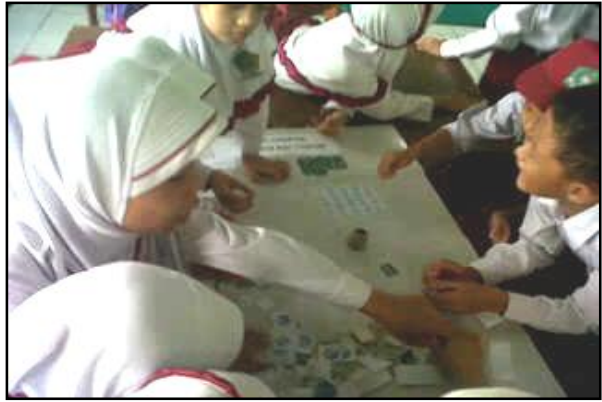

\section{Gambar 3. Siswa Berdiskusi dalam Kelompok}

Pada tahap kegiatan inti, siswa dari perwakilan kelompok mengambil berbagai mata uang tiruan yang disediakan guru dan siswa diminta memperhatikan petunjuk tugas berupa LKS yang akan dikerjakan dan berdiskusi dalam kelompoknya. Kegiatan ini merupakan proses penemuan dari konsep yang akan dipahami siswa. Guru membimbing siswa dalam mengerjakan penukaran uang. Setelah siswa selesai mengerjakan LKS, salah satu siswa maju ke depan untuk mempresentasikan hasil perkerjaannya.

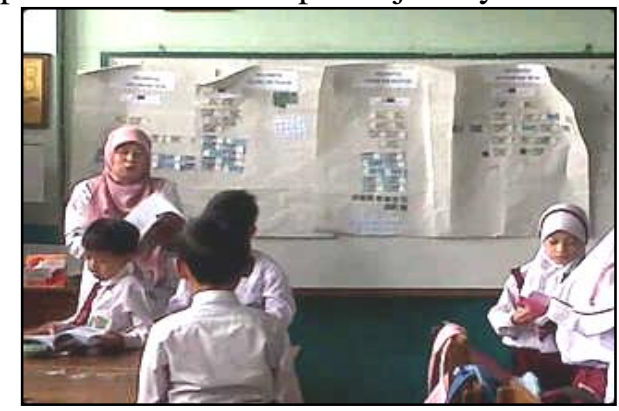

Gambar 4. Siswa Mempresentasikan Hasil Pekerjaannya

Pada akhir pembelajaran, guru melakukan refleksi terhadap hasil pekerjaan siswa dalam kelompok secara bersama-sama dan melakukan penilaian. Pada bagian ini sudah tercermin model vertikal yang disebut dengan iceberg, hanya saja konsep yang dipelajari siswa belum sampai kepada bentuk formal. Selanjutnya, guru memberikan Pekerjaan Rumah (PR) kepada siswa dari buku teks dan menutup pembelajaran dengan mengucapkan salam. Aktivitas pembelajaran ini sesuai dengan RPP yang telah dibuat guru sebelum mengajar.

\section{KESIMPULAN}

Berdasarkan hasil analisis data dan pembahasan disimpulkan bahwa penerapan pendekatan PMRI pada siswa kelas III di SDPN Sabang, SDPN Setiabudi, dan MIN Cicendo sudah terlaksana dengan baik. Dalam pembelajaran matematika penerapan pendekatan PMRI yang dilakukan pada ketiga sekolah tersebut, sebagai berikut:

1. Proses pembelajaran matematika diawali dengan masalah kontekstual dan diterapkan secara realistik agar dapat dipahami siswa. Sekolah yang menggunakan pembelajaran Tematik dari ketiga sekolah tersebut adalah SDPN Sabang, terlihat dari RPP yang dirancang guru bertemakan "Kegiatanku" untuk menjelaskan konsep Operasi Hitung Bilangan Sampai Tiga Angka.

2. Proses penemuan konsep oleh siswa di MIN Cicendo sudah berlangsung dengan baik, begitu juga dengan SDPN Sabang dan Setiabudi, hanya saja perlu dirancang lagi proses pembelajaran yang betul-betul melibatkan siswa dalam menemukan konsep tersebut agar tercapai model vertikal yang dinamakan dengan iceberg.

3. Hasil observasi di SDPN Setiabudi, guru tidak mempersiapkan RPP dan LKS dalam pembelajaran dengan pendekatan PMRI. Hal ini mungkin disebabkan karena guru tersebut sudah memahami kegiatan yang akan diajarkan dengan pendekatan PMRI sehingga beranggapan RPP bisa menyusul kemudian dan LKS diganti dengan menggunakan buku teks. Sedikit guru dari ketiga sekolah tersebut yang membuat materi RPP dari buku PMRI, hal ini dikarenakan guru ingin mencari media pembelajaran selain yang disajikan pada buku PMRI.

4. Pada umumnya guru dari ketiga sekolah yang menggunakan LKS, selalu membahas hasil pekerjaan siswa pada LKS tersebut. Siswa juga diberikan kesempatan untuk bertanya dan mengemukakan pendapat terhadap hasil pekerjaannya. Pada akhir pembelajaran, sebagian besar guru pada ketiga sekolah tersebut memiliki sedikit waktu untuk melakukan refleksi tentang materi yang dipelajari, hal ini disebabkan karena waktu pembelajaran banyak terpakai pada kegiatan inti ketika siswa memanipulasi alat peraga.

5. Pembelajaran dengan pendekatan PMRI membuat siswa aktif dan antusias dalam belajar. Hasil wawancara peneliti dengan sebagian kecil siswa diperoleh bahwa mereka senang dengan pembelajaran ini karena mereka mengalami langsung proses penemuan konsepnya dengan adanya LKS dan alat peraga yang menuntun mereka untuk sampai kepada bentuk formal dan memudahkan mereka memahami materi tanpa menghafalnya. 
Berdasarkan kesimpulan yang diperoleh, maka saran dalam penelitian ini, sebagai berikut:

1. Guru sebaiknya merancang dan menyusun RPP dan LKS sebelum menerapkan pembelajaran dengan pendekatan PMRI, hal ini bertujuan agar tujuan pembelajaran dapat tersampaikan dengan baik dan waktu yang terpakai dalam pembelajaran sesuai dengan rencana, sehingga tidak ada langkah-langkah pada RPP yang terabaikan. Berdasarkan wawancara peneliti dengan guru yang mengajar PMRI, pada umumnya menyatakan bahwa waktu yang diperlukan untuk menerapkan PMRI dalam pembelajaran tidak cukup, memang benar, tetapi jika guru dapat mengatur setiap kegiatan pembelajaran dengan alokasi waktu yang sudah ditentukan dalam RPP, maka masalah ini setidaknya dapat diminimalisir.

2. Alangkah baiknya guru selalu melakukan pengaitan konsep sebelumnya yang telah dipelajari siswa dengan konsep baru yang akan diajarkan, ini bertujuan untuk menjembatani pengetahuan baru yang diterima siswa dengan pengetahuan yang sudah dimilikinya, sehingga konsep formal dapat dipahami dengan baik oleh siswa.

3. Gunakan alat peraga yang efektif dan efisien dalam menjelaskan konsep yang disampaikan, sesuaikan alat peraga dengan kemampuan siswa dalam memanipulasinya. Jika siswa dapat menggunakan alat peraga dengan baik, maka konsep yang mereka pelajari dari alat peraga melalui aktivitas penemuan akan dikuasai dan awet dalam ingatannya.

4. Pembelajaran matematika dengan pendekatan PMRI sangat cocok diterapkan bagi siswa sekolah dasar, karena tahap perkembangan kognitif mereka pada umumnya berada pada operasi konkrit, perlu sekali mengawali pembelajaran dengan masalah kontekstual dan melakukan kegiatan penemuan melalui media alat peraga agar bisa memahami konsep yang formal.

\section{E. DAFTAR PUSTAKA}

Alwasilah, C. (2003). Pokoknya Kualitatif. Bandung: Kiblat Buku Utama.

Creswell, J. (2008). Educational Research: Planning, Conducting, and Evaluating Quantitative and Qualitative Research. New Jersey: Pearson-Merrill Prentice Hall.
Depdiknas. (2006). Undang-undang Sistem Pendidikan Nasional. Jakarta: Departemen Pendidikan Nasional.

Dickinson, et al. (2010). Using Realistic Mathematic Education with Low to Middle Attaining Pupils in Secondary Schools. British Congress of Mathematic Education (BCME-7) in Collaboration with the British Society for Research into Learning Mathematic, 30(1).

Fraenkel, J., et al. (2012). How to Design and Evaluate Research in Education. New York: McGrawHill.

Gravemeijer, K. (1994). Developing Realistic Mathematics Education. Utrecht: Freudhental Institute.

Hudoyo, H. (2000). Mengajar dan Belajar Matematika. Jakarta: Departemen Pendidikan dan Kebudayaan.

Kesumawati, N. (2008). Pendekatan Pendidikan Realistik untuk Pembelajaran Materi Bilangan. Makalah disajikan pada Seminar Nasional Penelitian, Pendidikan, dan Penerapan MIPA Yogyakarta, 30 Mei 2008.

Muchlis, E. E. (2012). Pengaruh Pendekatan Pendidikan Matematika Realistik Indonesia (PMRI) terhadap Perkembangan Kemampuan Pemecahan Masalah Siswa Kelas II SD Kartika 1.10 Padang. Jurnal Exacta, 10(2), 136-139.

Novikasari, I. (2007). Realistic Mathematic Education (RME) Pendekatan Pendidikan Matematika dalam Konsep dan Realitas. Jurnal Pemikiran Alternatif Pendidikan INSANIA, 12(1), 93-106.

Saefudin, A. A. (2012). Pengembangan Kemampuan Berpikir Kreatif Siswa dalam Pembelajaran Matematika dengan Pendekatan Pendidikan Matematika Realistik Indonesia (PMRI). Jurnal AlBidayah, 4(1), 37-48.

Permendiknas. (2008). Standar Kompetensi Lulusan Untuk Satuan Pendidikan Dasar dan Menengah. Jakarta: Departemen Pendidikan Nasional.

Sudharto, et al. (2009). Pengantar Ilmu Pendidikan. Semarang: IKIP PGRI.

Suherman, E., et al. (2003). Strategi Pembelajaran Matematika Kontemporer. Bandung: UPI.

Supinah \& Agus, D. W. (2009). Strategi Pembelajaran Matematika SD. Modul Depdiknas Direktoral Jenderal Peningkatan Mutu Pendidik dan Tenaga Kependidikan PPPPTK Matematika. 
Suryanto. (2001). Pendidikan Matematika

Realistik. Makalah disajikan pada Penataran Widyaiswara Matematika Balai Penataran Guru, PPPG Matematika Yogyakarta, 27 Maret s.d. 11 April 2001.

Tandililing, E. (2012). Implementasi PMRI (RME) di Sekolah. Jurnal UNTAN. Pontianak: PMIPA FKIP Universitas Tanjungpura.

Treffers, A. (1991). Didactical Background of a Mathematics Program for Primary Education. Dalam L. Streefland (ed.). Realistic Mathematics Education in Primary School. Utrecht: CD- $\beta$ Press/Freudhental Institute, Utrecht University. 